\title{
Noninvasive genetic census of greater one-horned rhinoceros Rhinoceros unicornis in Gorumara National Park, India: a pilot study for population estimation
}

Udayan Borthakur, Pranjal Kumar Das

Anjan Talukdar and Bibhab Kumar Talukdar

\begin{abstract}
The greater one-horned rhinoceros Rhinoceros unicornis is a flagship species for conservation in protected areas in India and Nepal. In India the species is afforded the highest level of legal protection under Schedule I of the Wildlife (Protection) Act 1972. Although censuses of greater one-horned rhinoceros have been carried out for decades using the traditional total count method, no advanced scientific approach has been adopted for population estimation of the species in India or elsewhere. We optimized noninvasive genetic techniques for identification of greater one-horned rhinoceros from dung samples, and applied these to estimate the number of rhinoceros in Gorumara National Park, in West Bengal, India. Our results confirmed the presence of 43 individuals from 60 dung samples collected throughout the Park in 2011. We confirmed a maleto-female sex ratio of $3.8: 1$, based on analysis of DNA from dung samples, using a y-chromosome linked marker. Our results are in concordance with a census carried out by the West Bengal Forest Department that found 42 rhinoceros in the Park, with a male-to-female sex ratio of 3.5 : 1. Our study thus demonstrates the feasibility of using a noninvasive genetic approach for population estimation of greater one-horned rhinoceros in the wild.
\end{abstract}

Keywords Census, Gorumara National Park, microsatellite, molecular sexing, noninvasive genetics, Rhinoceros unicornis, total count

To view supplementary material for this article, please visit http://dx.doi.org/10.1017/Soo30605314001161

\section{Introduction}

7 he greater one-horned rhinoceros Rhinoceros unicornis 1 is a Schedule I species under India's Wildlife (Protection) Act 1972, and is categorized as Vulnerable on the IUCN Red List (IUCN, 2013). The species was once

Udayan Borthakur (Corresponding author), Pranjal Kumar Das, Anjan Talukdar and Bibhab Kumar Talukdar Aaranyak, 50, Samanwoy Path, Survey, P.O. Beltola, Guwahati 781028, Assam, India

E-mail udayan@aaranyak.org, udayan.borthakur@gmail.com

Received 30 November 2013. Revision requested 27 February 2014.

Accepted 2 December 2014. First published online 11 February 2016. distributed throughout the northern floodplains and the Himalayan foothills of the Indian subcontinent, between the Indo-Myanmar border in the east and Pakistan's Sindhu river basin in the west (Rao, 1957; Laurie et al., 1983; Leader-Williams, 2013) but as a result of habitat destruction and poaching for its horn it is now confined to a few isolated patches in protected areas in India and Nepal (Laurie et al., 1983; Talukdar et al., 2008). The Indian population of greater one-horned rhinoceros accounts for $>70 \%$ of the global population of the species (Talukdar et al., 2008) and is spread across seven protected areas: Kaziranga National Park, Orang National Park, Pobitora Wildlife Sanctuary and Manas National Park in the state of Assam, Gorumara National Park and Jaldapara National Park in the state of West Bengal, and Dudhwa National Park in the state of Uttar Pradesh.

Accurate estimation of population size is of paramount importance in the conservation and management of threatened species, to assess conservation needs and evaluate effects of conservation actions (Gese, 2001). Population monitoring of white rhinoceros Ceratotherium simum and black rhinoceros Diceros bicornis in Africa has been carried out using various techniques, including identification based on distinct body features (Conway \& Goodman, 1989; Kiwia, 1989; Walpole et al., 2001; Patton et al., 2007), radio-tagging (Galli \& Flamand, 1995), spoor (Alibhai et al., 2008) and camera-trapping (Stein et al., 2010), aerial counts from aircraft, using multiple observers (Brockett, 2002; Ngene et al., 2011), and counts at water holes, using photographic records (Cilliers, 1989). In Nepal, photographs of individual onehorned rhinoceros have been used to estimate the minimum population size in Chitwan National Park (Laurie, 1978; Dinerstein \& Price, 1991). Rhinoceros populations have also been monitored by observers riding elephants, using a total block count method to identify individual rhinoceros based on features such as horn shape, skin folds and body marks (Subedi et al., 2013). In India the rhinoceros has been censused using a total count method, whereby rhinoceros are counted by observers riding elephants; multiple teams count the total number of individuals observed in assigned blocks, which are generally demarcated by physical boundaries such as rivers, streams or roads (Lahan \& Sonowal, 1973). Unlike the block count method used in Nepal, the total count method adopted in India does not 
strictly employ individual identification based on distinct body features.

In recent years noninvasive genetic approaches have emerged as an alternative to invasive capture-mark-recapture methods, providing an opportunity to identify individuals without the need to capture, harm or disturb them (Taberlet et al., 1996, 1999; Kohn et al., 1999; Smith et al., 2006; Borthakur et al., 2013). There are a number of potential benefits to genetic tagging compared with physical tagging (Taberlet et al., 1999), including an increase in the number of records (yielding more accurate estimates), reduced stress and mortality, reduced capture bias caused by trap response, and a shorter sampling period to approximate closure better (Miller et al., 2005). The estimation of population size by means of noninvasive genetic sampling and capture-mark-recapture models is a complex multistep process, which involves an appropriate sampling design (Lindberg \& Rexstad, 2002; Boulanger et al., 2004), effective field techniques, a reliable protocol of individual identification (Paetkau, 2003), and adequate capture-mark-recapture modelling for population estimation (Mondol et al., 2009).

We conducted a genetic-tagging-based census of greater one-horned rhinoceros in Gorumara National Park. Our objective was to optimize protocols for genetic identification from dung samples so that this approach, with development of a robust sampling strategy, could be used for geneticbased estimation of the population size of the species in the wild across India.

\section{Study area}

The c. $80 \mathrm{~km}^{2}$ Gorumara National Park lies in the floodplains of the Murti and Raidak rivers, in the state of West Bengal (Fig. 1). This region is part of the Eastern Himalayan submontane Terai belt and the Indo-Malayan ecozone. Gorumara was chosen as the study site because of its known small population of rhinoceros ( 42 individuals), with a male-to-female sex ratio of 3.5:1 (according to the March 2012 census conducted by West Bengal Forest Department using the total count method).

\section{Methods}

Technical details of the genetic analysis are provided as Supplementary Material.

Field survey and sample collection The field survey was undertaken during April 2011 by UB and PKD accompanied by the field staff of Gorumara Forest Department, to locate fresh samples of rhinoceros dung, preferably deposited no more than 24 hours prior to

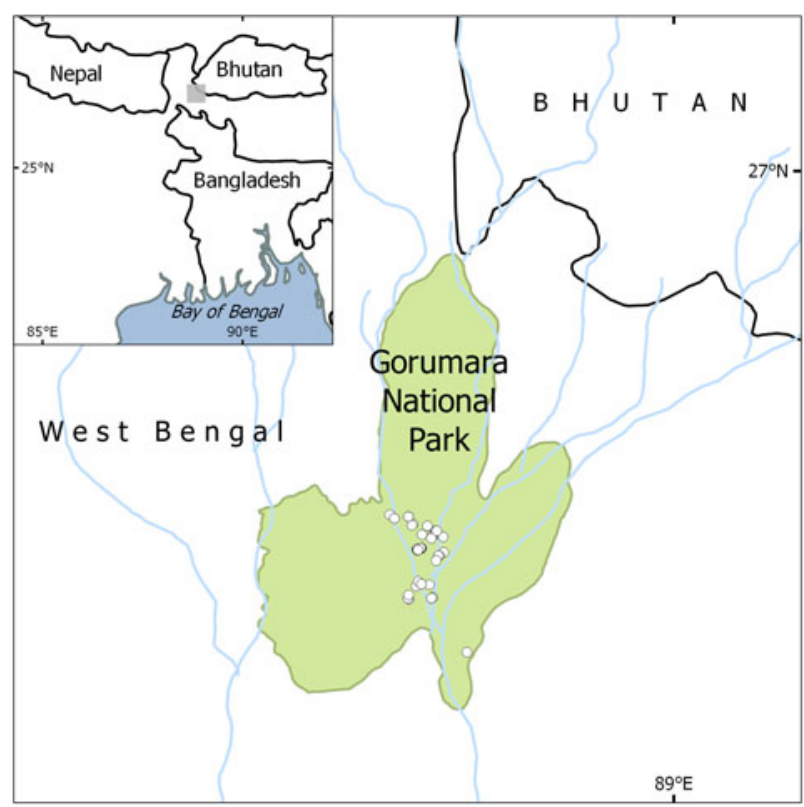

FIG. 1 Sites where samples of greater one-horned rhinoceros Rhinoceros unicornis dung were collected in Gorumara National Park, West Bengal.

collection. Elephants were used throughout the survey for transportation in areas that could not be accessed by vehicles. Circa $15^{-20} \mathrm{~g}$ of dung from each sample was collected in plastic vials containing DMSO-EDTA-Trissalt saturated (DETs) buffer. The geographical coordinates of each sample were recorded using a global positioning system. We collected 6o samples of rhinoceros dung from Gorumara National Park during April 2011 (Fig. 1). We also extracted DNA from 10 reference tissue samples from dead rhinoceros, collected during 2008-2009 and preserved in $95 \%$ ethanol, for use in marker standardization. All samples were kept at a temperature of $-20^{\circ} \mathrm{C}$ prior to DNA extraction.

DNA extraction DNA was extracted from dung samples using the guanidine isothiocyanate-silica-based protocol (Boom et al., 1990), with modifications (see Supplementary Material for full details). All DNA extractions were performed in a room dedicated for low-quality DNA work. DNA extractions from reference tissues and samples were performed using the DNeasy Blood \& Tissue kit (QIAGEN, Hilden, Germany), following standard kit protocols.

Selection of polymorphic microsatellite markers and individual identification Seventeen microsatellite loci (Table 1), nine from greater one-horned rhinoceros (Zschokke et al., 2003) and eight from Sumatran rhinoceros Dicerorhinus sumatrensis (Scott et al., 2004), were first screened on 10 reference samples from greater 
TABLE 1 Details of microsatellite markers screened on 10 reference samples of greater one-horned rhinoceros Rhinoceros unicornis to select a panel of polymorphic loci for identification of individual rhinoceros in Gorumara National Park, West Bengal (Fig. 1).

\begin{tabular}{|c|c|c|c|c|c|c|c|c|c|}
\hline $\begin{array}{l}\text { Sample } \\
\text { no. }\end{array}$ & Locus & $\begin{array}{l}\text { No. of } \\
\text { alleles }\end{array}$ & $\begin{array}{l}\text { Allele } \\
\text { range }\end{array}$ & $\begin{array}{l}\% \text { PCR } \\
\text { success }\end{array}$ & $\begin{array}{l}\text { Allele } \\
\text { dropout }\end{array}$ & $\begin{array}{l}\text { False } \\
\text { alleles }\end{array}$ & $\begin{array}{l}\text { Expected } \\
\text { heterozygosity }\end{array}$ & $\begin{array}{l}\text { Observed } \\
\text { heterozygosity }\end{array}$ & Reference \\
\hline 1 & SR54 & 1 & 184 & 100 & 0 & 0 & 0 & 0 & Scott et al. (2004) \\
\hline 2 & SR63 & 4 & $205-219$ & 100 & 0 & 0 & 0.62 & 0.5 & Scott et al. (2004) \\
\hline 3 & SRIIIA & 5 & $100-116$ & 100 & 0 & 0 & 0.63 & 1 & Scott et al. (2004) \\
\hline 4 & SRIIIB & 5 & $123-131$ & 100 & 0 & 0 & 0.72 & 0.8 & Scott et al. (2004) \\
\hline 5 & SR191 & 1 & 178 & 100 & 0 & 0 & 0 & 0 & Scott et al. (2004) \\
\hline 6 & SR261 & 1 & 171 & 100 & 0 & 0 & 0 & 0 & Scott et al. (2004) \\
\hline 7 & SR74 & 2 & $150-162$ & 100 & 0 & 0 & 0.46 & 0.7 & Scott et al. (2004) \\
\hline 8 & SR281 & 4 & $216-236$ & 100 & 0 & 0 & 0.72 & 0.8 & Scott et al. (2004) \\
\hline 9 & Rh1 & 3 & $148-154$ & 100 & 0 & 0 & 0.65 & 0.8 & Zschokke et al. (2003) \\
\hline 10 & Rh3 & 3 & $116-150$ & 100 & 0 & 0 & 0.62 & 0.5 & Zschokke et al. (2003) \\
\hline 11 & $\mathrm{Rh} 4$ & 4 & $89-101$ & 100 & 0 & 0 & 0.74 & 0.7 & Zschokke et al. (2003) \\
\hline 12 & Rh5 & 4 & $196-206$ & 100 & 0 & 0 & 0.74 & 0.9 & Zschokke et al. (2003) \\
\hline 13 & Rh6 & 2 & $120-122$ & 100 & 0 & 0 & 0.38 & 0.4 & Zschokke et al. (2003) \\
\hline 14 & Rh7 & 2 & $202-204$ & 100 & 0 & 0 & 0.48 & 0.1 & Zschokke et al. (2003) \\
\hline 15 & Rh9 & 2 & $150-174$ & 100 & 0 & 0 & 0.13 & 0.1 & Zschokke et al. (2003) \\
\hline 16 & Rh10 & 5 & $138-148$ & 100 & 0 & 0 & 0.58 & 0.7 & Zschokke et al. (2003) \\
\hline 17 & Rh11 & 4 & $143-155$ & 100 & 0 & 0 & 0.5 & 0.5 & Zschokke et al. (2003) \\
\hline
\end{tabular}

one-horned rhinoceros to determine the level of polymorphism. The selected polymorphic loci (Table 2) were used to genotype the samples of rhinoceros dung. We used a multiple tube approach (Taberlet et al., 1996), assigning quality indices to the genotype data, following Miquel et al. (2006) for genotyping quality control and assessment of genotyping error (see Supplementary Material for full details).

Sex identification of rhinoceros We used Ychromosome-specific SRY (sex-determining region of the Y chromosome) primers designed from horse SRY sequences (primers were designed at the Center for Conservation and Research of Endangered Wildlife, Cincinnati Zoo \& Botanical Garden, USA). Microsatellite locus SRIIIA (108-116 bp) was used as nuclear control in a multiplex reaction with the SRY (165 bp) marker to distinguish between PCR failures and female samples in a single-tube PCR. Male samples were identified by the presence of both SRY and SRIIIA PCR products, and female samples were identified by the presence of only SRIIIA products (see Supplementary Material for full details).

\section{Results}

Three of the 17 microsatellite loci on the reference tissue samples (SR54, SR191 and SR261) were found to be monomorphic (Table 1). The observed heterozygosity was o-1.0 across the 17 loci, and the mean values of expected and observed heterozygosity were 0.47 and 0.50 , respectively. The
PCR success rate was $100 \%$ for all loci; no allelic dropout or false alleles were observed for any of the loci in reference samples. Three of the loci, SR63 $\left(\chi^{2}=13.16, \mathrm{df}=6\right.$, $\mathrm{P}<0.05)$, SRIIIA $\left(\chi^{2}=30.0, \mathrm{df}=10, \mathrm{P}<0.001\right)$ and $\mathrm{Rh} 7$ $\left(\chi^{2}=5.284, \mathrm{df}=1, \mathrm{P}<0.05\right)$, were found to deviate significantly from Hardy-Weinberg equilibrium, with no linkage disequilibrium. On the basis of the three criteria described in the Methods, 12 polymorphic loci were selected for genotyping the rhinoceros dung samples. The cumulative values of probability of identity and probability of identity among siblings of these 12 loci were found to be as low as $2.8 \cdot 10^{-8}$ and $4.2 \cdot 10^{-4}$, respectively, which indicates the high resolving power of these loci in the identification of individual rhinoceros. Figure 2 is a graphical representation of the cumulative values of probability of identity and probability of identity among siblings for all 17 loci, in increasing order of single locus value, for the 10 reference samples.

In accordance with quality index criteria, genotype data for 56 dung samples were retained for identification of unique multilocus genotypes and determination of the number of individual rhinoceros. The number of alleles, allele size range, percentage PCR success, allelic dropout, false alleles, and expected and observed heterozygosity for the 12 microsatellite loci in the 56 samples are presented in Table 2. Locus Rh1 was found to be monomorphic in the Gorumara population. The observed heterozygosity was o-0.66 across the 12 loci, and mean expected and observed values were 0.35 and 0.36 , respectively. PCR success was 72$90 \%$ across the 12 loci, and an overall genotyping error rate of $2 \%$ was observed. The cumulative probability of identity and probability of identity among siblings were $1.18 \cdot 10^{-4}$ and $1.17 \cdot 10^{-2}$, respectively. Figure 3 is a graphical 
TABLE 2 Details of the 12 polymorphic microsatellites selected from 56 samples of rhinoceros dung samples of unknown individual identity.

\begin{tabular}{|c|c|c|c|c|c|c|c|c|c|}
\hline Locus & $\begin{array}{l}\text { No. of } \\
\text { alleles }\end{array}$ & Allele range & $\begin{array}{l}\% \text { PCR } \\
\text { success }\end{array}$ & $\begin{array}{l}\text { Allele } \\
\text { dropout }\end{array}$ & $\begin{array}{l}\text { False } \\
\text { alleles }\end{array}$ & $\begin{array}{l}\text { Expected } \\
\text { heterozygosity }\end{array}$ & $\begin{array}{l}\text { Observed } \\
\text { heterozygosity }\end{array}$ & $\begin{array}{l}\text { Multiplex } \\
\text { panel }\end{array}$ & $\begin{array}{l}\text { Temperature } \\
\left({ }^{\circ} \mathrm{C}\right)\end{array}$ \\
\hline$\overline{\mathrm{Rh} 3}$ & 4 & $116-150$ & 78 & 0.03 & 0.05 & 0.52 & 0.52 & $\mathrm{~A}$ & 55 \\
\hline $\mathrm{Rh} 4$ & 2 & $93-95$ & 90 & 0.00 & 0.00 & 0.23 & 0.26 & & \\
\hline Rh10 & 3 & $138-146$ & 76 & 0.04 & 0.07 & 0.55 & 0.38 & & \\
\hline Rh7 & 3 & $200-204$ & 77 & 0.04 & 0.00 & 0.52 & 0.54 & B & 55 \\
\hline Rh9 & 2 & $148-150$ & 87 & 0.00 & 0.00 & 0.42 & 0.52 & & \\
\hline Rh11 & 4 & $149-155$ & 72 & 0.04 & 0.05 & 0.59 & 0.66 & & \\
\hline Rh1 & 1 & 152 & 90 & 0.00 & 0.00 & 0 & 0 & $\mathrm{C}$ & 52 \\
\hline Rh5 & 3 & $196-206$ & 87 & 0.05 & 0.00 & 0.26 & 0.22 & & \\
\hline Rh6 & 2 & $120-122$ & 87 & 0.00 & 0.00 & 0.08 & 0.04 & & \\
\hline SRIIIA & 3 & $108-116$ & 90 & 0.00 & 0.03 & 0.14 & 0.14 & $\mathrm{D}$ & 61 \\
\hline SR63 & 2 & $215-217$ & 77 & 0.04 & 0.03 & 0.36 & 0.36 & & \\
\hline SR281 & 2 & $231-233$ & 72 & 0.02 & 0.04 & 0.49 & 0.66 & & \\
\hline
\end{tabular}

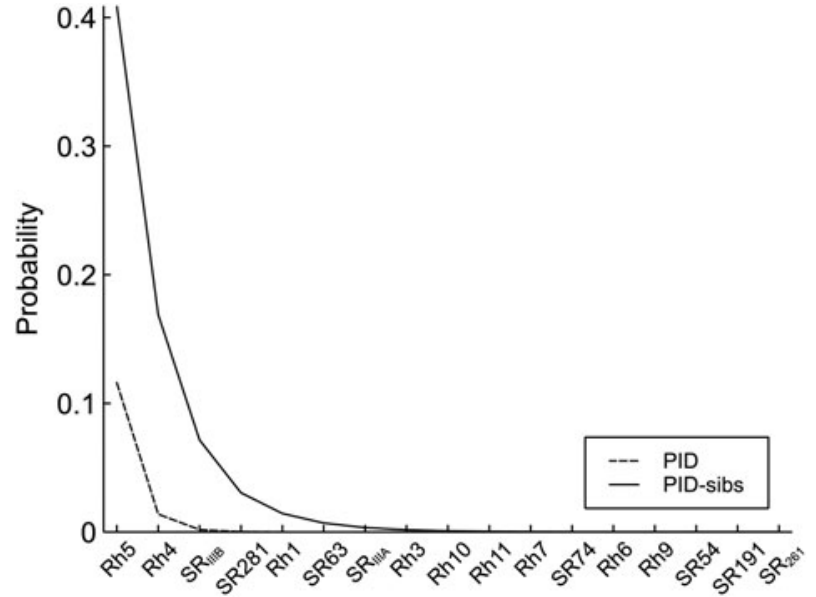

FIG. 2 Cumulative values of probability of identity and probability of identity among siblings for 17 microsatellite loci screened on 10 reference samples of rhinoceros dung.

representation of the cumulative values of probability of identity and probability of identity among siblings for the 12 polymorphic loci, in increasing order of single locus value, for the 56 dung samples. Significant deviation from Hardy-Weinberg equilibrium was observed in six loci: Rh1o $\left(\chi^{2}=7.902, \mathrm{df}=3, \mathrm{P}<0.05\right)$, Rh9 $\left(\chi^{2}=8.074, \mathrm{df}=1\right.$, $\mathrm{P}<0.01), \quad$ Rh11 $\quad\left(\chi^{2}=19.572, \quad \mathrm{df}=6, \quad \mathrm{P}<0.01\right), \quad \mathrm{Rh} 5$ $\left(\chi^{2}=43.976, \mathrm{df}=3, \mathrm{P}<0.001\right), \mathrm{Rh} 6\left(\chi^{2}=10.979, \mathrm{df}=1\right.$, $\mathrm{P}<0.001)$ and SR281 $\left(\chi^{2}=18.289, \mathrm{df}=1, \mathrm{P}<0.001\right)$. No linkage disequilibrium was observed in any of the loci in the 56 dung samples.

Individual identity analysis yielded 43 unique multilocus genotypes in the 56 samples, confirming the presence of 43 individual rhinoceros in Gorumara during the sampling period. Identification of unique multilocus genotypes based on zero and single locus mismatch yielded the same number of individuals. Sex identification analysis indicated there were 34 male and nine female rhinoceros (a male-to-female sex ratio of 3.8:1).

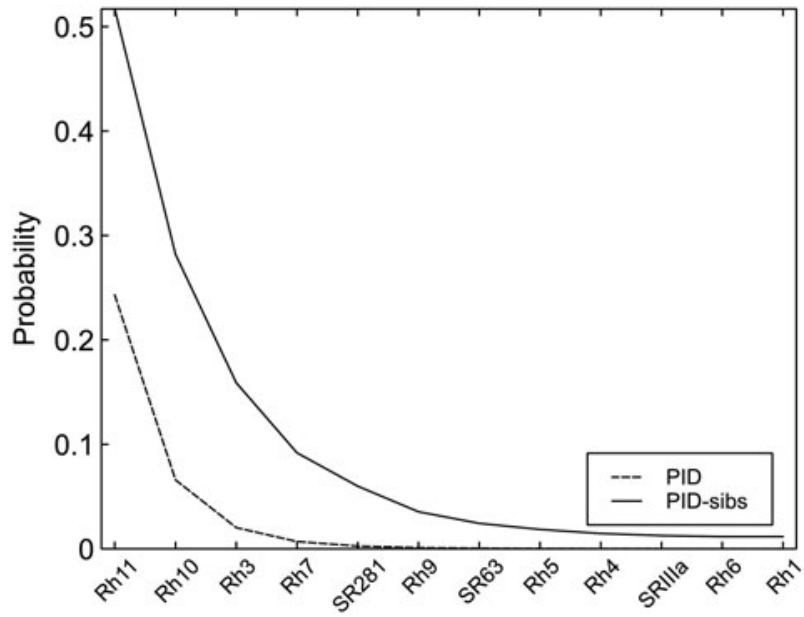

FIG. 3 Cumulative values of probability of identity and probability of identity among siblings for 12 polymorphic microsatellite loci from 56 samples of rhinoceros dung.

\section{Discussion}

We used noninvasive genetic techniques to identify individual greater one-horned rhinoceros in Gorumara National Park. The 12 microsatellite loci selected indicated low probability of identity $\left(1.18 \cdot 10^{-4}\right)$ and probability of identity among siblings of $1.17 \cdot 10^{-2}$ for the dung samples collected. These values are comparable to those found in other studies (Vidya et al., 2007; Flagstad et al., 2012). The cut-off number of loci for individual identification was a trade-off between a high probability of identity and increasing risk of introducing higher genotyping error by additional loci, as suggested in other studies (Borthakur et al., 2011; Flagstad et al., 2012).

Quality index criteria allowed $93 \%$ of samples to be retained for final analysis, which is a higher proportion than in other studies (e.g. Flagstad et al., 2012). Using a quality index cut-off value of 0.625 retained $68 \%$ of samples of elephant dung stored in ethanol; Borthakur et al. (2011), using a quality index cut-off value of 0.667 , retained only $50 \%$ of 
tiger dung samples stored in silica gel. The mean PCR amplification success was $82 \%$, which is comparable to that reported for other species (e.g. 95\% for elephants; Fernando et al., 2003). Vidya \& Sukumar (2005) also reported high overall microsatellite PCR amplification success (95.6\%) with dung samples, with varied success across loci, as observed in our study.

In 2012 the West Bengal Forest Department counted 42 rhinoceros in Gorumara, with a male-to-female sex ratio of 3.5:1 (Department of Environment, Government of West Bengal). Our results are similar ( 43 and $3.8: 1$, respectively). The genetic-based total count is practical and cost effective for small populations such as in Gorumara, where obtaining samples from every rhinoceros is possible. A comparative analysis of the costs involved in the genetic-based total count and traditional total count methods is not within the scope of this study, however, because data for the latter are unavailable. Generating individual genetic profiles for all rhinoceroses within a protected area provides scope for long-term population monitoring, yielding information on the dispersal of individuals and other parameters required to study the dynamics of a natural population. For large populations, however, such as that of Assam's Kaziranga National Park $(>2,300$ rhinoceroses according to a total count census conducted by Assam Forest Department in 2013), sampling strategies need to be developed further to facilitate the use of genetic tools for population monitoring.

Genetic monitoring can provide information on various aspects of genetic diversity, but for regular monitoring purposes the traditional total count method is easier for forest departments to implement. This is primarily because of the need for technical expertise and laboratory facilities rather than because of the costs involved. We recommend a multidisciplinary approach to monitoring populations of greater one-horned rhinoceros in India, based on a combination of traditional and advanced ecological and genetic monitoring techniques, to provide the necessary data for conservation management of the species in situ.

UB conceived the study design, carried out the field work and data analysis, wrote the manuscript and provided guidance to PKD. PKD took part in the field work and carried out the laboratory work. AT participated in the collection of reference tissue samples. BKT contributed towards research planning and collection of reference samples.

\section{Acknowledgements}

We thank the West Bengal Forest Department for providing the necessary permission to undertake this work. We thank the Conservation of Forests, Wildlife (north) and the Divisional Forest Officer, Wildlife Division II, Jalpaiguri, West Bengal, for providing the necessary support in undertaking the field work. We thank Mr Bimal
Debnath, Range Officer, Gorumara, for his support in the field, and guidance during sample collection in Gorumara National Park. We thank Drs Terri Roth, Monica Stoops and Douglas Winget of the Center for Conservation and Research of Endangered Wildlife, Cincinnati Zoo and Botanical Garden, USA, for sharing their primer sequences for rhinoceros sex identification. We thank Ms Rumi Dev Barman and Mr Dipul Saikia of Wildlife Genetics Laboratory, Aaranyak, for their support in the laboratory, and we thank all the officials of Aaranyak for their active support during this work. We thank our donors Taiwan Forestry Bureau and the Asian Rhino Project, Australia, for their financial support of this work.

\section{References}

Alibhai, S.K., Jewell, Z.C. \& Law, P.R. (2008) A footprint technique to identify white rhino Ceratotherium simum at individual and species levels. Endangered Species Research, 4, 205-218.

Boom, R., Sol, C.J.A., Salimans, M.M.M., Jansen, C.L., Wertheim-van Dillen, P.M.E. \& van der NoordaA, J. (1990) Rapid and simple method for purification of nucleic acids. Journal of Clinical Microbiology, 28, 495-503.

Borthakur, U., Barman, R.D., Das, C., Basumatary, A., Talukdar, A., Ahmed, M.F. et al. (2011) Noninvasive genetic monitoring of tiger (Panthera tigris tigris) population of Orang National Park in the Brahmaputra floodplain, Assam, India. European Journal of Wildlife Research, 57, 603-613.

Borthakur, U., Saini, R.P., Gupta, S.S., Jakher, R., Das, C., Das, A.K. et al. (2013) Noninvasive genetic assessment of population status of tigers (Panthera tigris tigris) in Buxa Tiger Reserve, West Bengal, India. International Journal of Biodiversity and Conservation, 5, 27-32.

Boulanger, J., McLellan, B.N., Woods, J.G., Proctor, M.F. \& Strobeck, C. (2004) Sampling design and bias in DNA-based capture-mark-recapture population and density estimates of grizzly bears. The Journal of Wildlife Management, 68, 457-469.

Brocketт, B.H. (2002) Accuracy, bias and precision of helicopterbased counts of black rhinoceros in Pilanesberg National Park, South Africa. South African Journal of Wildlife Research, 32, 121-136.

Cilliers, A. (1989) Monitoring methods and techniques for censusing black rhinoceros Diceros bicornis bicornis in Etosha National Park. KOEDOE, 32, 49-60.

Conway, A.J. \& Goodman, P.S. (1989) Population characteristics and management of black rhinoceros Diceros bicornis minor and white rhinoceros Ceratotherium simum simum in Ndumu Game Reserve, South Africa. Biological Conservation, 47, 109-122.

Dinerstein, E. \& Price, L. (1991) Demography and habitat use by greater one-horned rhinoceros in Nepal. The Journal of Wildlife Management, 55, 401-411.

Excoffier, L., Laval, G. \& Schneider, S. (2005) Arlequin (version 3.0): an integrated software package for population genetics data analysis. Evolutionary Bioinformatics Online, 1, 47-50.

Fernando, P., Vidya, T.N.C., Rajapakse, C., Dangolla, A. \& MeLnick, D.J. (2003) Reliable noninvasive genotyping: fantasy or reality? Journal of Heredity, 94, 115-123.

Flagstad, O., Pradhan, N.M.B., Kvernstuen, L.G. \& Wegge, P. (2012) Conserving small and fragmented populations of large mammals: non-invasive genetic sampling in an isolated population 
of Asian elephants in Nepal. Journal for Nature Conservation, 20, 181-190.

Galli, N.S. \& Flamand, J.R.B. (1995) Darting and marking black rhinoceros on foot: part of a monitoring and population estimation technique in Hluhluwe-Umfolozi Park, South Africa. Pachyderm, 20, 33-38.

Gese, E.M. (2001) Monitoring of terrestrial carnivore populations. In Carnivore Conservation (eds J.L. Gittleman, S.M. Funk, D.W. Macdonald \& R.K. Wayne), pp. 372-396. Cambridge University Press, Cambridge, UK.

IUCN (2013) IUCN Red List of Threatened Species v. 2013.2. Http:// www.iucnredlist.org [accessed 20 November 2013].

Kalinowski, S.T., Taper, M.L. \& Marshall, T.C. (2007) Revising how the computer program CERVUS accommodates genotyping error increases success in paternity assignment. Molecular Ecology, $16,1099-1106$.

Kiwia, H.D. (1989) Black rhinoceros (Diceros bicornis (L.)): population size and structure in Ngorogoro Crater, Tanzania. African Journal of Ecology, 27, 1-6.

Kohn, M.H., York, E.C., Kamradt, D.A., Haught, G., Sauvajot, R.M. \& WAYNe, R.K. (1999) Estimating population size by genotyping faeces. Proceedings of the Royal Society B, 266, 657-663.

Lahan, P. \& Sonowal, R.N. (1973) Kaziranga Wildlife Sanctuary, Assam: a brief description and report on the census of large animals. Journal of Bombay Natural History Society, 70, 245-277.

LAURIE, W.A. (1978) The ecology and behaviour of the greater one-horned rhinoceros. $\mathrm{PhD}$ thesis. University of Cambridge, Cambridge, UK.

Laurie, W.A., Lang, E.M. \& Groves, C.P. (1983) Rhinoceros unicornis. Mammalian Species, 211, 1-6.

Leader-Williams, N. (2013) Fate riding on their horns-and genes? Oryx, 47, 311-312.

Lindierg, M. \& Rexstad, E. (2002) Capture-recapture sampling designs. In Encyclopaedia of Environmetrics (eds A.H. El-Shaarawi \& W.W. Piegorsch), pp. 251-262. John Wiley \& Sons, Chichester, UK.

Marshall, T.C., Slate, J., KruUk, L.E.B. \& Pemberton, J.M. (1998) Statistical confidence for likelihood-based paternity inference in natural populations. Molecular Ecology, 7, 639-655.

Miller, C.R., Joyce, P. \& Waits, L.P. (2005) A new method for estimating the size of small populations from genetic markrecapture data. Molecular Ecology, 14, 1991-2005.

Miquel, C., Bellemain, E., Poillot, C., Bessière, J., Durand, A. \& TABerlet, P. (2006) Quality indexes to assess the reliability of genotypes in studies using noninvasive sampling and multiple-tube approach. Molecular Ecology Notes, 6, 985-988.

Mondol, S., Karanth, K.U., Kumar, N.S., Gopalaswamy, A.M., Andheria, A. \& Ramakrishnan, U. (2009) Evaluation of non-invasive genetic sampling methods for estimating tiger population size. Biological Conservation, 142, 2350-2360.

Ngene, S., Bitok, E., Mukeka, J., Gakuya, F., Omondi, P., Kimitei, K. et al. (2011) Census and ear-notching of black rhinos (Diceros bicornis michaeli) in Tsavo East National Park, Kenya. Pachyderm, 49, 61-69.

PAETKAU, D. (2003) An empirical exploration of data quality in DNA-based population inventories. Molecular Ecology, 12, 1375-1387.

Patton, F., Campbell, P. \& Parfet, E. (2007) Establishing a monitoring system for black rhinos in the Solio Game Reserve, central Kenya. Pachyderm, 43, 87-95.

RAO, H.S. (1957) History of our knowledge of the Indian fauna through the ages. Journal of the Bombay Natural History Society, 54, 251-280.

Scott, C., Foose, T., Morales, J. C., Fernando, P., Melnick, D. J., BoAG, P. T. et al. (2004) Optimization of novel polymorphic microsatellites in the endangered Sumatran rhinoceros

(Dicerorhinus sumatrensis). Molecular Ecology Notes, 4, 194-196.

Smith, D.A., Ralls, K., Hurt, A., Adams, B., Parker, M. \& Maldonado, J.E. (2006) Assessing reliability of microsatellite genotypes from kit fox faecal samples using genetic and GIS analyses. Molecular Ecology, 15, 387-406.

Stein, A.B., Erckie, B., Fuller, T.K. \& Marker, L. (2010) Camera trapping as a method for monitoring rhino populations within the Waterberg Plateau Park, Namibia. Pachyderm, 48, 67-70.

Subedi, N., Jnawali, S.R., Dhakala, M., Pradhan, N.M.B., Lamichinanea, B.R., Malla, S. et al. (2013) Population status, structure and distribution of the greater one-horned rhinoceros Rhinoceros unicornis in Nepal. Oryx, 47, 352-360.

Taberlet, P., Griffin, S., Goossens, B., Questiau, S., Manceau, V., Escaravage, N. et al. (1996) Reliable genotyping of samples with very low DNA quantities using PCR. Nucleic Acids Research, 24, 3189-3194.

Taberlet, P., Waits, L.P. \& Luikart, G. (1999) Noninvasive genetic sampling: look before you leap. Trends in Ecology and Evolution, 14, 323-327.

Talukdar, B.K., Emslie, R., Bist, S.S., Choudhury, A., Ellis, S., Bonal, B.S. et al. (2008) Rhinoceros unicornis. In IUCN Red List of Threatened Species v. 2012.2. Http://www.iucnredlist.org.

VALIÈRE, N. (2002) GIMLET: a computer program for analysing genetic individual identification data. Molecular Ecology Notes, 2, 377-379.

Vidya, T.N.C. \& Sukumar, R. (2005) Amplification success and feasibility of using microsatellite loci amplified from dung to population genetic studies of the Asian elephant (Elephas maximus). Current Science, 88, 489-492.

Vidya, T.N.C., VARma, S., Dang, N.X., Thanh, T.V. \& Sukumar, R. (2007) Minimum population size, genetic diversity, and social structure of the Asian elephant in Cat Tien National Park and its adjoining areas, Vietnam, based on molecular genetic analyses. Conservation Genetics, 8, 1471-1478.

Walpole, M.J., Morgan-Davies, M., Milledge, S., Bett, P. \& Leader-Williams, N. (2001) Population dynamics and future conservation of a free-ranging black rhinoceros (Diceros bicornis) population in Kenya. Biological Conservation, 99, 237-243.

Zschokke, S., Gautschi, B. \& Baur, B. (2003) Polymorphic microsatellite loci in the endangered Indian rhinoceros, Rhinoceros unicornis. Molecular Ecology Notes, 3, 233-235.

\section{Biographical sketches}

UDAYAN BORTHAKUR uses noninvasive sampling techniques for genetic monitoring of threatened species, including tigers and greater one-horned rhinoceroses in India, Javan and Sumatran rhinoceroses in Indonesia, and snow leopards and white-bellied herons in Bhutan. $\mathrm{He}$ is a member of the IUCN SSC Asian Rhino Specialist Group. PR AN J A KUMAR DAS is researching population genetics of the greater onehorned rhinoceros in India. He has also contributed to ongoing research on noninvasive genetic monitoring of threatened species in India and Bhutan. ANJAN TALUKDAR is a wildlife veterinarian. $\mathrm{He}$ has been involved in the rehabilitation and translocation of wild onehorned rhinoceroses in Kaziranga National Park, and has carried out research on the sedative and analgesic effects of romifidine in Asian elephants. Biвнав KUMAR TALUKDAR is focused on research and conservation of the three rhinoceros species in South and South-east Asia. He is Chair of IUCN SSC Asian Rhino Specialist Group. 